\title{
Presentation of sex work in two Costa Rican newspapers: a multivariate analysis of the roles of patriarchal prejudice and reporter gender
}

\author{
Julián Monge-Nájera ${ }^{1}$, Karla Vega Corrales ${ }^{1}$ and María Isabel González Lutz ${ }^{2}$ \\ 1. Laboratorio de Ecología Urbana, Vicerrectoría de Investigación, Universidad Estatal a Distancia, 2050 San José, Costa Rica; \\ julianmonge@gmail.com \\ 2. Escuela de Estadística, Universidad de Costa Rica, 2060 San José, Costa Rica; kantr.vega@gmail.com; mariaisabel.gonzalezlutz@ucr.ac.cr
}

Received 15-I-2013 Corrected 29-IV-2013 Accepted 6-VII-2013

\begin{abstract}
Traditionally, patriarchal societies have repressed women who practice sex work. Today, that repression continues through mass media. In this article we analyze the treatment given to sex worker coverage in the two printed newspaper with the largest circulation in Costa Rica: Diario Extra and La Nación. We recorded all news mentioning sex work in both newspapers during the year 2010 and applied a logistic regression analysis to indicators. To study the association of these indicators with the newspaper and gender of the reporter, we used contingency tables and likelihood ratios. The majority of the 56 reporters who wrote the news items were men and most of the news items related with sex work had a social approach, followed by those with criminal and morality approaches. The articles tend to present sex workers as being outside the law (even though sex work is legal in Costa Rica) and in conflict with other social actors. Despite scientific findings that show otherwise, the media continue to spread myths about frequent "exploitation" and "child prostitution".
\end{abstract}

\section{KEY WORDS}

Influence of mass media on public opinion, discrimination of minorities, lack of objectivity in reporting

\section{RESUMEN}

Tradicionalmente, las sociedades patriarcales reprimen a las mujeres que practican el trabajo sexual y en ello participan hoy los medios de comunicación masiva. Aquí analizamos el tratamiento dado a la cobertura del tema en dos de los principales periódicos impresos de Costa Rica: Diario Extra y La Nación. Recopilamos todas las noticias en las que se mencionó el trabajo sexual en ambos periódicos durante el año 2010 y aplicamos una regresión logística de indicadores. Aplicamos tablas de contingencia y cocientes de probabilidad para medir la asociación de los indicadores con el periódico y el sexo de quien escribe. La mayoría de los 56 periodistas eran hombres y la mayoría de las noticias tuvo un enfoque social (seguidos por los enfoques criminal y moral). A pesar de que el trabajo sexual es legal en Costa Rica, los artículos tienden a presentar a las trabajadoras sexuales como fuera de la ley y "en conflicto" con otros actores sociales. Aunque los hallazgos científicos muestran lo contrario, estos diarios siguen generalizando mitos acerca de la frecuente "explotación" y"prostitución infantil".

\section{PALABRAS CLAVE}

Influencia de los medios de comunicación en la opinión pública, discriminación de minorías, falta de objetividad
In the patriarchate, human sexuality is treated as an intrinsically bad and "dirty" phenomenon that is tolerated only for reproductive purposes and within the limits of official marriage. Furthermore, women are considered inferior to men, and this explains why female sexual workers are at the bottom of the hierarchy: they are both women and workers in a "dirty business" (Eagly \& Wood, 1999; Buss \& Duntley, 2008; Monge-Nájera, Rojas, Morales \& Ramírez, 2009). Some forms of humiliation and violence seem to be warranted under the patriarchate according to Gallego (2011) and religions are active enforcers of patriarchal prejudice against sexual work and those who practice it (Juliano, 2005).

Despite social repression, some women practice sex work and other activities associated with their sexuality when it is their only option, while others freely chose this kind or work among other options because it pays well (Rojas, Monge-Nájera, Ramírez \& Morales, 2009; 
Rivers-Moore 2010). In a related area, glamour and nude modeling, the way in which women describe their bodies and personalities reflect their belief that they can use their own sexuality as a road to success beyond the traditional stereotype of "dependent females" (Monge \& Vega, 2011).

According to Juliano (2005), to keep women under control, the patriarchate presents a distorted image of transgressor women: they become stigmatized, and the fear of stigma keeps many women away from the unwanted behavior. There is a symbolic violence that serves as basis for other forms of violence against women: the differences of female sex workers with other women are emphasized and the similarities are hidden.

The mass media keep the public informed, but also maintain and strengthen official views about values, identity and stereotypes, including the stigmatization of sex work (Marocco, 2002); this allows the public to feel better by comparison, because they are not lazy, prostitutes, poor, criminal and similar concepts. Furthermore, the media are considered more authoritative than informal sources and thus have more real impact on public opinion, in detriment of the rejected minorities (Wegener, 2010).

In general, the media treat women and men differently. The linguistic and discursive mechanisms to deny women an active role in society include, according to Rovetto (2010):

1. Women are rarely mentioned in headlines in particular and in the news in general

2. Their activities are frequently presented according to gender stereotypes

3. Their affective or sexual relationships with men are gratuitously mentioned

In the case of female sex workers, the media reflect their patriarchal ideology by one of two basic options: sex workers are either ignored or presented in a distorted way. The media can present them from the point of view of others (usually men such as policemen, neighbors, lawyers), and their opinions are "invisible" in that they are not included or are presented in a less important way (Bustos, 2010). According to Juliano (2005) sex workers often are absent from the media except when the news allows them to be presented according to the patriarchal prejudice as bad and inferior. For example, the image of these "bad women" who act as home-wreckers persists even when studies found that the stable clientele is composed of married men who stay married (Ramírez, Monge-Nájera, Rojas \& Morales, 2009).

Even where sex work is legal, the news about female sex workers are automatically associated with criminality by including them in the "red section"together with drugs, exploitation and similar topics (Bustos, 2010).

In this article we analyze the treatment given to sex worker coverage in two mass media companies from Costa Rica, La Nación and Extra. La Nación, the most influential right-wing newspaper in Costa Rica, is addressed to the middle and high class readers, with a small red note section. Diario Extra, with a slightly higher circulation than La Nación, is addressed to the lower classes and has a larger red note section. We consider its political views more centered than those of La Nación.

In this article we compare the news by gender of the narrator and analyze whether the news about sex work are associated with criminality by including them in the "red section" along with drugs, alcohol abuse, exploitation or other similar topics. Our hypothesis is that the treatment given to sex work in Diario Extra is more sensationalist but less hostile than the one given by La Nación.

\section{MATERIALS AND METHODS}

Before collecting data, our team participated in a workshop based on the study by Igartua \& Humanes (2004) and chose the variables to be measured (the complete resulting dataset is in the digital Appendix 1, available at www. uned.ac.cr/investigacio/publicaciones/cuaderno1/). Thus, the variables represent a collective agreement on which variables would give a good view of the phenomenom.

We recorded all news mentioning sex work in La Nación and Diario Extra during the year 2010. We filled a data form for each news item and applied a multivariate analysis with JMP version 8 by building indicators as follows:

- Topic: a negative point if the topic was moral, medical, social or criminal, a positive point if the topic was economic or otherwise.

- Sources of communication: a positive point if the source identified was the academic sector, a negative point for any other source.

- Actors involved: a positive point if the actor was the sex worker or an academic, a negative point for any other actor.

- Social dynamics: a negative point for news presented as conflict or complaint, a positive point for others.

- Intention of the sender: a positive point if the presentation was friendly to sex workers, a negative point if it was hostile, zero points for any other approach.

- Indirect ways of referring to the workers: a positive point if they were rhetorical or comparative; a negative point if they were judgmental. 
- Indirect ways of referring to sex work: a positive point if they were rhetorical or comparative; a negative point if they were judgmental.

To study the association of these indicators with the newspaper and gender of the reporter, we used contingency tables and likelihood ratios with a significance level of $5 \%$.

In order to determine how much each of these indicators helped to predict the newspaper in which it was reported, we used a logistic regression analysis. The same was done for the reporter's gender.

Other indicators that we observed to study their relationship with the newspaper and reporter gender were the words alcoholism, poverty, drug use, slums, child prostitution, sex tourism, exploitation, abuse, trafficking, slavery, violence, rape in childhood, cross-dressing and illegality. The association was also studied with likelihood ratios (significance level: 5\%).

A

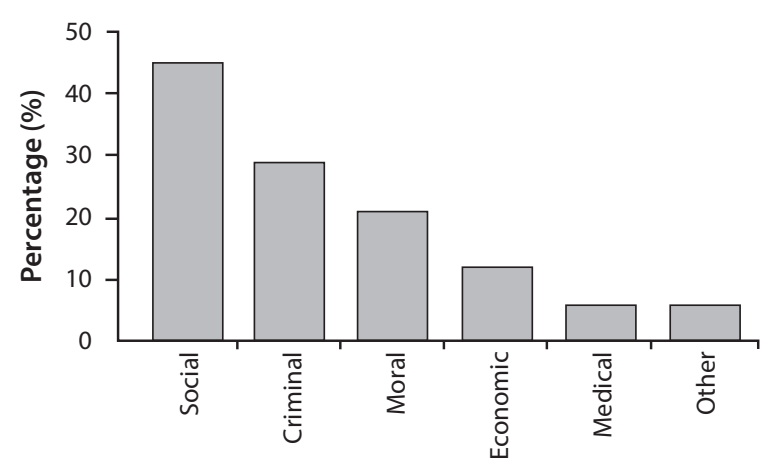

C

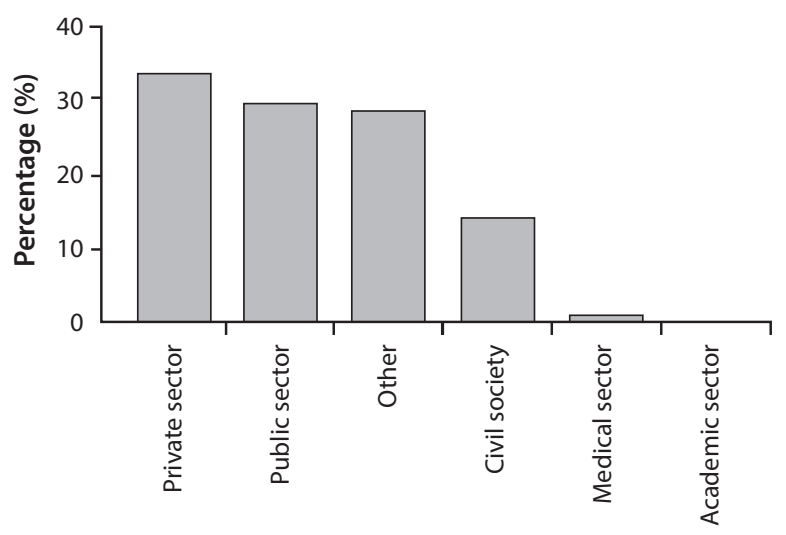

\section{RESULTS}

\section{Sample description}

Most of the 56 reporters (43) were men, but there were enough women in the sample to allow for a statistical gender comparison.

Most of the news items related with sex work had a social approach, followed by those with criminally and morality approaches. Economic and medical approaches were less common but still represented together about $15 \%$ of the articles (Fig. 1).

Very few reports about sex work in Costa Rica published by Diario Extra and La Nación have a friendly view focused on consensus or positive propositions. On the contrary, most present sex work as a source of conflict or openly denounce it. The closest to a balanced view is the category of simply descriptive news, that represent about one fifth of all news (Fig. 2 and 3).

B

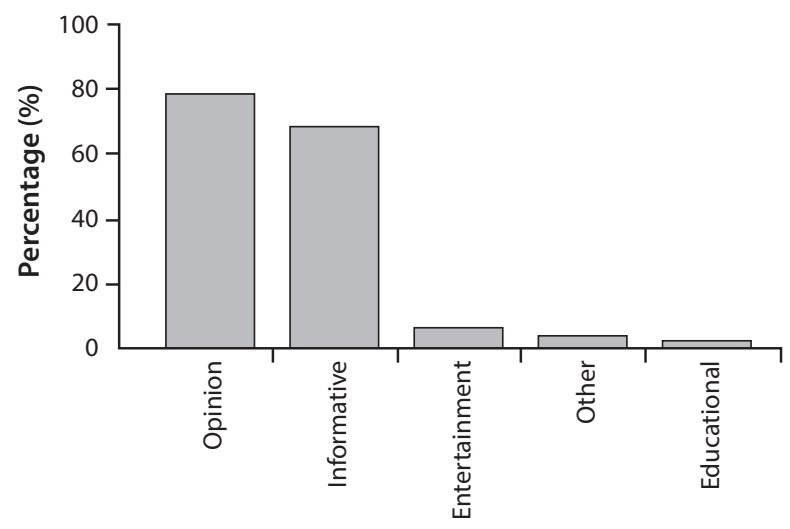

D

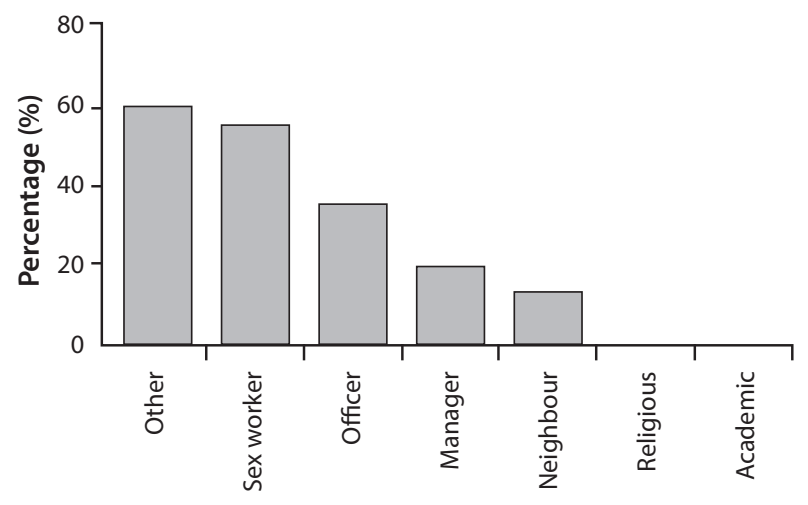

FIG. 1. (A, B, C, D) Approach, type of news, sources of information and social actor involved in the news mentioning sex work in two Costa Rican daily newspapers, La Nación and Diario Extra, during the year 2010. 
A

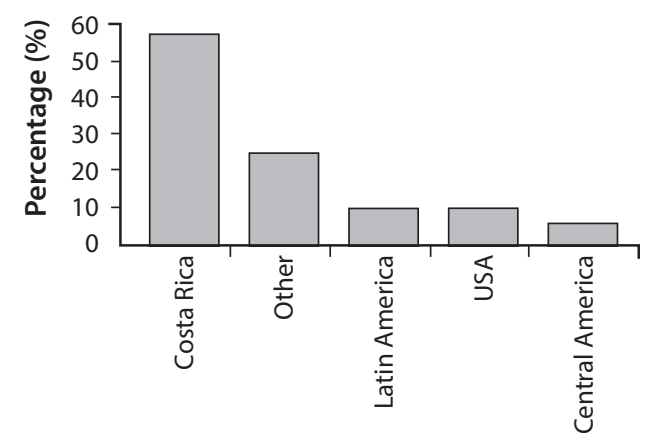

C

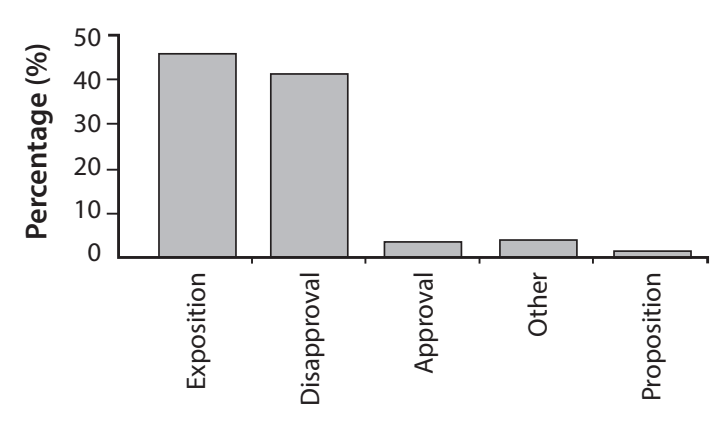

B

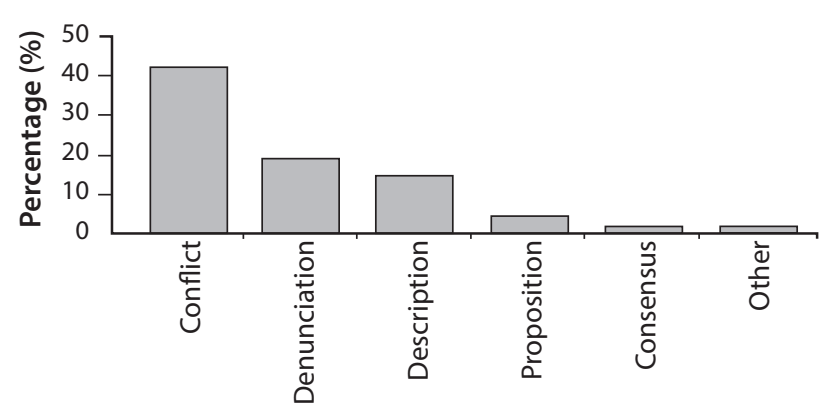

D

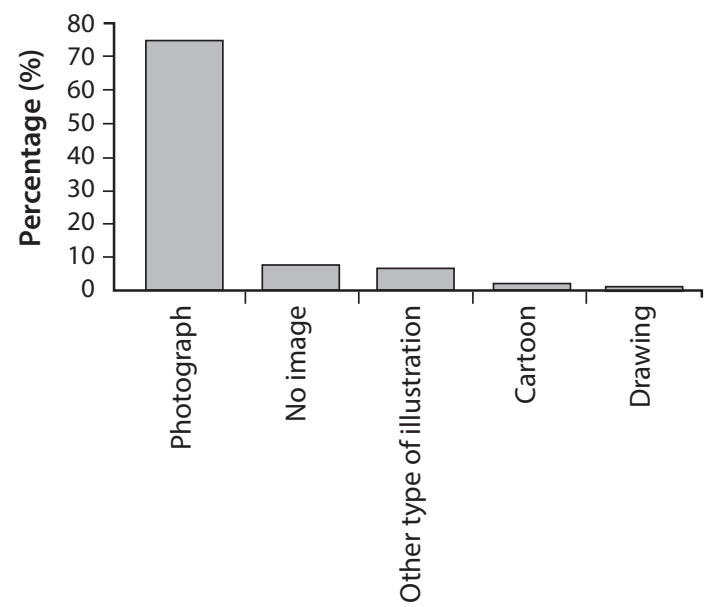

FIG. 2. (A, B, C, D) Site where the news take place, social dynamics described, author position and type of illustration in news mentioning sex work in two Costa Rican daily newspapers, La Nación and Diario Extra, during the year 2010.

A

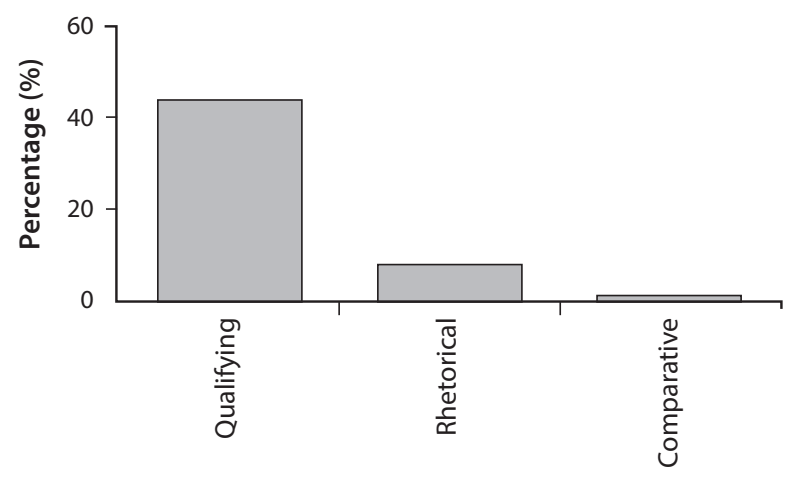

B

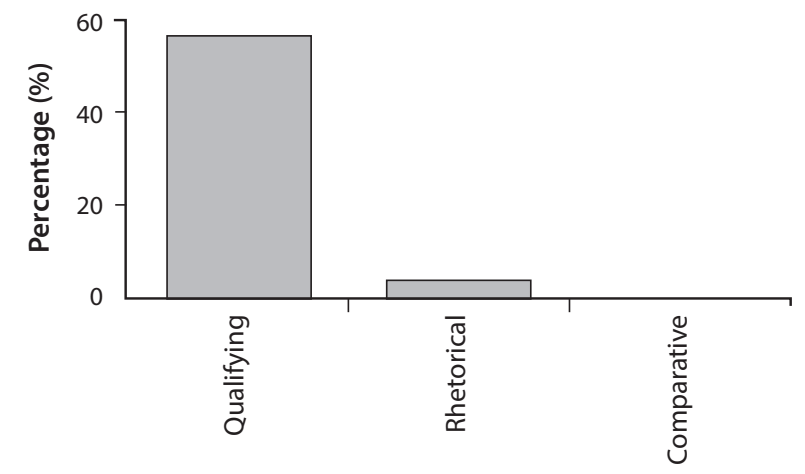

FIG 3. Indirect ways of naming the sex work in articles mentioning sex work in two Costa Rican daily newspapers, during the year 2010, (A) La Nación, (B) Diario Extra. 
A large number of articles do not mention the nationality of the sex workers, and we can hypothesize that they are assumed to be Costa Ricans because normally the nationality is given in the Police sections of both newspapers whenever the subjects are foreigner. Nevertheless, one quarter of the news did mention Costa Rica as the nationality.

Our impression as viewers of television news is that many sex workers in Costa Rica are Nicaraguan, Colombian or Dominican, and we wanted to see if this was reflected in the newspapers that we studied here. Indeed that was the case, with the unexpected result that Italians appeared in more news that Dominicans, but this possibly reflects the fact that we did not separate news about sex work in Costa Rica from the infrequent but existing news in the Costa Rican press about sex work in other countries. Such data pooling can explain why even origins that quite probably are not represented among Costa Rican sex workers, such as Egypt, Somalia and Turkey, appear in the list of countries of nationality even if they are very few and do not affect the trends we identified here (Fig. 4).

\section{Inferential analysis}

\section{Description of indicators}

The indicators were constructed so that each of the integrated items accumulated a negative point if the treatment agrees with a patriarchal prejudice, zero points if the treatment is neutral and positive if it is against prejudice. The items that made up each of the indicators were not identified in advance in the template, they were added when found; for this reason, the minimum and maximum values of each indicator are different. Appendix 1 shows the minimum and maximum values available and observed for each indicator.

Only one news item did not associate sexual work with crime or other negative and socially condemned aspects. Most of the news associated sex work with at least one and sometimes up to four negative social aspects.

The association of indicators with the newspaper presents the results of a logistic regression analysis performed to test the hypothesis that the treatment given to sex work is different depending on the media. Only the Actor indicator is correlated with the newspaper: for every unit of the associated indicator in La Nación there are 1.68 units of association in the Diario Extra.

\section{Association of indicators with gender of the writer}

We also tested the hypothesis that the treatment given to sex work depends on the gender of the reporter who wrote the news items. The sex of the writer does
A

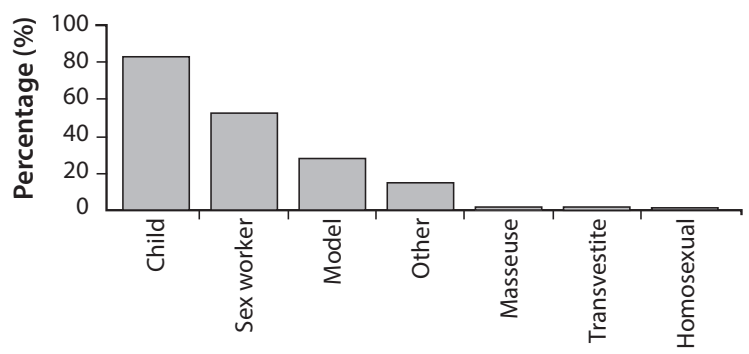

B
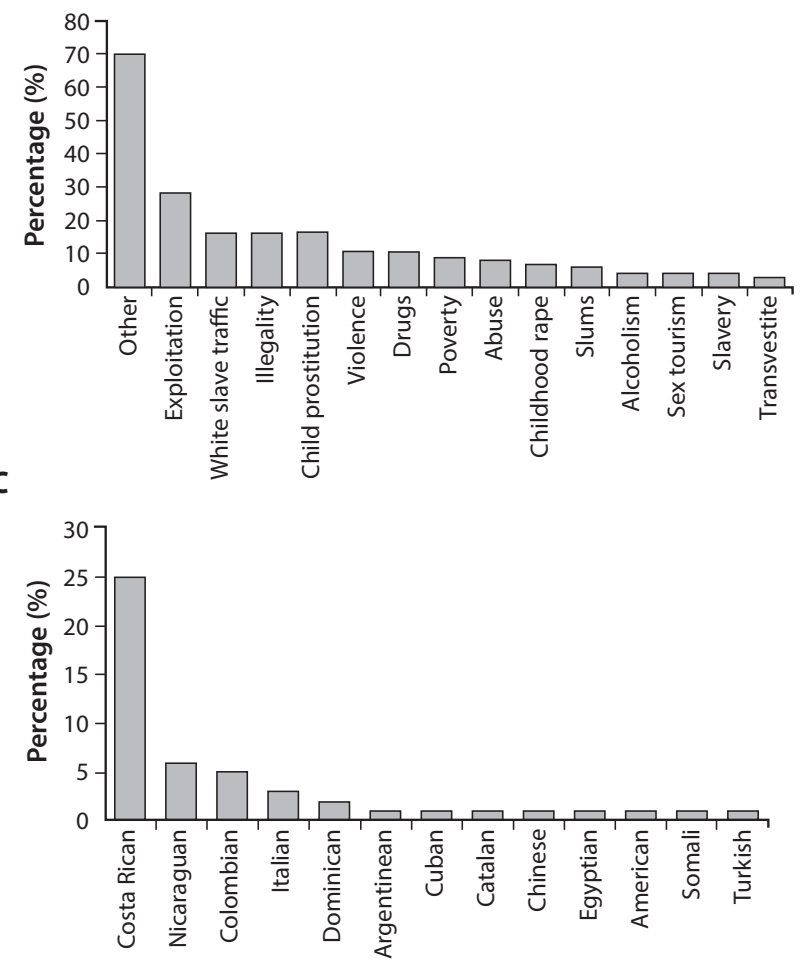

FIG. 4. (A, B, C) Who does the sex work, association of sex work with other activities and nationality of persons engaging in sex work in two Costa Rican daily newspapers, La Nación and Diario Extra, during the year 2010.

not affect the content: men and women appear to be equally prejudiced.

Finally, we studied whether the indicators behave differently according to who does the sex work. We only found significant differences for association with criminality and for the indirect way of labeling the workers. The writers associated sex work with less negative aspects when it is done by "prostitutes" or by models. On the other hand, the indirect way of labeling the workers is less aggressive when the workers are "young girls". 


\section{DISCUSSION}

Socially, image and discourse not only reflect, but also shape political views about sex work (Wegener, 2010). The media reports are more than the stories they present, there is a subjacent element that constructs and perpetuates the ideological view of the reporters and the media (Acevedo, 2009). This is in agreement with our finding that even though the social approach is the most frequent, it is closely followed by the crime and morality approaches and to some extent, the opinion and information sections are the most frequent locations of the articles. Nevertheless, the low frequency of medical approaches could mean that the media has lost confidence in the groundless view of sex workers as significant vectors of AIDS and other sexual diseases.

Like in other studies (e.g. Bustos, 2010) we found that the media "speak" about sex workers, not with them. The reporters ask others, usually men, to describe, judge and brand them. Basically, sex workers are excluded as a source of information about themselves: reporters do not give them a voice (Bustos, 2010). Furthermore, the reporters falsely associate sex work with crime, do not mention that it is legal work (using the degrading word "prostitution" instead) and do not ask the academic sector for a more objective view of this type of work.

The scarcity of news about sex work outside Costa Rica, with the exception of a few news items about Costa Rican women doing sex work abroad, reflects the strong focus on local news that, in our experience, characterizes the leading Costa Rican media.

Through fantasy and stigmatization, sex workers are turned into something different from other women (Wegener, 2010). This is done by most of the articles in the two Costa Rican newspapers considered in our study. This kind of degrading treatment applies not only to sex workers, but also to other minorities (Igartua, 2004)

Like Bustos (2010) we found that the media presents sex workers as being outside the law and in conflict with other social actors, but we disagree with Bustos on her acceptance of the myth of the "exploitation view" of sex work, which has been shown to be a belief without ground for the current sex work scene in Costa Rica (Monge et al., 2009; Ramírez et al., 2009; Rojas et al., 2009; Rivers-Moore, 2010; Monge et al., 2011).

The press articles degrade the image of sex workers and are fully in agreement with the patriarchate ideology that praises the dependent woman who stays at home to rear the offspring and rejects independent women who work outside the house, especially if their work is of sexual nature (Rovetto, 2010).
In Western culture media, the images of sex work do not necessarily reflect reality; rather they reflect the beliefs that some people, usually unacquainted with the subject, have about sex work (Wegener, 2010). Like Wegener (2010) states, the images used as illustrations by the media show what reporters believe is the mainstream sex work scene, rather than the real scene (Monge et al., 2009; Monge et al., 2011; Ramírez et al., 2009; Rojas, 2009).

By always presenting male sex workers as "travestites" the media distorts reality, publishing statements that distinguish among "good citizens, prostitutes and drug dealers" (Bustos, 2010). Sex workers are portrayed in a circumscribed and negative manner, similar to findings published for other countries by Collins (2011). The presentation of sex workers as voiceless criminals by the Costa Rican press is not different from the generalization made by Rovetto (2010).

It is not strange that the media also present sex workers as predominatly foreigners, despite the fact that they are mostly Costa Rican (Monge, et al., 2009), because female immigrants are perceived as social appendices of male immigrants and share their bad image (Oso, 1998; Rovetto, 2010).

Collins (2011) wrote that while increasing the representation of women in media may be valuable, there is a need to avoid increasing negative or stereotypical depictions, precisely the kind of depictions used by these newspapers. This is dangerous because sensationalist media reporting can lead to a deterioration of the working and living conditions for sex workers (Schuster, 2010).

At least for the urban area that has been seriously studied, in Costa Rica sex work is done almost exclusively by adults who keep all their profits for their own use (Monge et al., 2009). There are no studies about who benefit from the myth about the abundance of exploited child prostitutes that is widely believed by the population. In conclusion, the Costa Rican newspapers studied here are still a long way from presenting a science-based image of sex work that is compassionate and fair to the people who do this kind of work.

\section{ACKNOWLEDGMENTS}

We thank the assistance of Raquel Ramero and Pamela Campos, as well as the support of Guiselle Bustos and Víctor Méndez. Our special thanks to Katya Calderón for her encouragement and for assigning financial support and to Lizette Brenes for continuing that support. 


\section{REFERENCES}

Acevedo, M. (2009). Mujeres en situación de prostitución de calle y su representación en medios gráficos: La historieta "Clara de noche". Anagramas, 7(14), 33-48.

Buss, D.M., \& Duntley, J.D. (2008). Adaptations for exploitation. Group Dynamics: Theory, Research, and Practice, 12, 53-62.

Bustos, G. (2010). Control social y violencia en la representación del trabajo sexual: de los años cuarenta a los relatos de Diario Extra hoy. Comunicación, 19(1), 13-23.

Collins, R. (2011). Content Analysis of Gender Roles in Media: Where Are We Now and Where Should We Go? Sex Roles, 64(3-4), 290-298. doi: 10.1007/s11199-010-9929-5

Eagly, A., \& Wood, W. (1999). The origins of sex differences in human behavior: Evolved dispositions versus social roles. American Psychologist, 54(6): 408-423. doi: 10.1037/0003-066X.54.6.408

Gallego, J. (2011). Prostitutas, chaperos y escorts. Reflexiones sobre la sexualidad de pago en la ficción cinematográfica. Memoria III Jornadas Mujer y medios de comunicación. Universidad del País Vasco. PP. 71-86

Igartua, J., \& Humanes, M. (2004). Imágenes de Latinoamérica en la prensa española. Una aproximación empírica desde la Teoría del Encuadre. Communication and Society/Comunicación y Sociedad, 17(1), 47-75.

Juliano, D. (2005). El trabajo sexual en la mira. Polémicas y estereotipos. Cuadernos Pagu, 25, 79-107

Marocco, B. (2002). Prostitutas, jugadores, pobres y vagos en los discursos periodísticos. Tesis doctoral. Departamento de periodismo y ciencias de la comunicación. Universidad Autónoma de Barcelona, España.

Monge-Nájera, J., Rojas Campos R., Morales Bonilla, R., \& Ramírez, S. (2009). Trabajo sexual femenino en la ciudad de San
José, Costa Rica: un enfoque sociobiológico al iniciarse el siglo XXI. Cuadernos de Investigación UNED, 1(1), 27-31.

Monge-Nájera, J., \& Vega Corrales, K. (2011). Self view of women's bodies and characteristics in early glamour website models. Cuadernos de Investigación UNED, 3(1), 45-51

Oso, L. (1998). Migración, Género y Hogares Transnacionales. Universidad de Coruña, España.

Ramírez Sánchez, I, Monge-Nájera, J., Rojas Campos, R., \& Morales Bonilla, R. (2009). La escolaridad en trabajadoras sexuales de la ciudad de San José, Costa Rica, al iniciarse el siglo XXI. Cuadernos de Investigación UNED, 1(1), 33-42.

Rivers-Moore, M. (2010). But the kids are ok: Motherhood, consumption and sex work in neoliberal Latin America. British Journal of Sociology, 61(4), 716- 736.

Rojas Campos, R, Monge-Nájera, J., Ramírez Sánchez, I., \& Morales Bonilla, R. (2009). El mercado de trabajo sexual femenino en la ciudad de San José, Costa Rica. Cuadernos de Investigación UNED, 1(1), 13-25.

Rovetto, F. (2010). La representación del trabajo de las mujeres en los medios de comunicación: el caso de las mujeres inmigrantes. Nómadas. Revista Crítica de Ciencias Sociales y Jurídicas, 28(4), 113-127

Schuster, M., Sülzle, A., \& Zimowska, A. (2010). Discourse on prostitution and human trafficking in the context of UEFA EURO 2012. Academic study of discourse and campaigns in the run-up to the 2012 European Football Championship finals as the basis for advising decision-makers. UEFA, Nyon, Switzerland.

Wegener, L. (2010). Asomo de esperanza o mala luz La prostitución en los Países Bajos: política e imágenes en la prensa. Programa de Maestría de Comunicación Intercultural. Facultad de Humanidades, Universidad de Utrecht, Países Bajos.

\section{Article edited by Vanessa Nielsen-Muñoz}


